\title{
PENGARUH PEMAKAIAN ARANG BATOK KELAPA TERHADAP KUAT TEKAN BETON K225
}

\author{
Dodi Riyanto $^{(1)}$, Hendra Cahyadi ${ }^{(2)}$, Rida Respati ${ }^{(3)}$ \\ Alumni Fak.Teknik UM Palangka Raya ${ }^{(1)}$ \\ Program Studi Teknik Sipil UM Palangka Raya ${ }^{(2)(3)}$
}

\begin{abstract}
ABSTRAK
Beton adalah material komposit terdiri dari bahan dasar semen, agregat kasar, agregat halus, air dan dengan atau tanpa bahan tambahan dengan perbandingan tertentu akan membentuk beton. Pada penelitian ini menggunakan bahan arang batok kelapa desa kalampangan untuk campuran beton K225 sebagai pengganti agregat halus terhadap persentasi berat, variasi 7,5\%,10\% dan $12,5 \%$ yang bertujuan untuk mengetahui seberapa besar kuat tekan setelah dilakukan pencampuran arang batok kelapa.

Tahapan penelitian dimulai dari persiapan material, pengujian agregat kasar (batu pecah), agregat halus (pasir), setelah memenuhi spesifikasi dilakukan pembuatan campuran beton normal dan pembuatan beton menggunakan arang batok kelapa, pengujian kuat tekan,anasisa data, kemudian kesimpulan dan saran.

Prosedur penelitian dibagi menjadi dua tahap, yaitu: penelitian awal untuk menentukan kuat tekan beton normal dan penelitian kedua untuk menentukan kuat tekan beton dengan menggunakan campuran arang batok kelapa 7,5\%, 10\% dan 12,5\% terhadap berat agregat halus (pasir).

Hasil penelitian menunjukan kuat tekan beton normal rata-rata adalah $314,45 \mathrm{~kg} / \mathrm{cm}^{2}$, setelah penggunaan arang batok kelapa 7,5\% kuat tekan rata-rata sebesar $340,08 \mathrm{~kg} / \mathrm{cm}^{2}$, kemudian pada penggunaan arang batok kelapa $10 \%$ didapat kuat tekan rata-rata $332,78 \mathrm{~kg} / \mathrm{cm}^{2}$, pada penggunaan arang batok kelapa $12,5 \%$ kuat tekan rata-rata $305,08 \mathrm{~kg} / \mathrm{cm}^{2}$. Berdasarkan hasil penelitian disarankan pemakaian arang batok kelapa tidak melebihi $10 \%$ karena jika pemakaian melebihi $10 \%$ kuat tekan beton akan mengalami penurunan.
\end{abstract}

Kata Kunci: Beton Normal, Arang Batok Kelapa, Kuat Tekan 
Pengaruh Pemakaian Arang Batok Kelapa ..., Dodi ${ }^{(1)}, \operatorname{Hendra}^{(2)}, \operatorname{Rida}^{(3)}$

\section{Latar Belakang}

Sumber daya alam di negara kita tersedia cukup melimpah, namun tidak bisa dikatakan tak terbatas, pemanfaatan sumber daya alam haruslah diusahakan sehingga mencapai daya guna dan tepat guna yang sebesar-besarnya. Dalam sejarah selalu menuntut untuk meningkakan pembangunan sarana dan prasarana yang dianggap vital oleh suatu negara, misalnya pembangunan perumahan, perkantoran ataupun untuk pendidikan, guna mencapai peningkatan dan pemerataan kesejahteraan serta kemakmuran masyarakat, bangsa dan negara.

Suatu kreatifitas dalam menciptakan kreasi kontruksi dengan melakukan rekayasarekayasa konstruksi yang bersifat sederhana. Namun dalam rekayasa kontruksi ini harus diperhatikan juga bagaimana tingkat keamanan dan kelayakan dari rekayasa tersebut. Perkembangan beton juga maju dengan pesat sehingga bisa dimuat beton mutu tinggi. Pemakaian beton mutu tinggi akan memberikan beberapa keuntungan diantaranya, dimensi elemen struktur bisa lebih kecil/langsing. Dalam PBI 1971, beton untuk konstruksi dibagi dalam mutu dan kelasnya, yaitu beton non struktural dan beton struktural. Beton non struktural adalah beton Bo, sedangkan beton struktural adalah beton yang mempunyai nilai tekan karakteristik K-125, k-175, K-225, dan seterusnya.

Dalam penelitian ini hanya difokuskan terhadap beton K-225 sebagai bahan campur dasar beton terdiri dari semen, agregat halus (pasir), agregat kasar. Kekuatan beton ditentukan oleh karakteristik material pembentuk tersebut, selain itu kekuatan beton juga ditentukan oleh kepadatanya. Sekarang untuk mencapai kepadatan tersebut, orang banyak mencampur dengan bahan fly ash. Karena pemakaian fly ash sudah begitu banyak, maka harga material ini sudah relatif meningkat. Untuk pengganti bahan ini, maka diambil alternatif dengan mengganti arang batok kelapa. Adapun alasan pengambilan alternatif ini karena kandungan abu arang batok kelapa ini menunjukan adanya kesamaan dengan fly ash arang tempurung batok kelapa juga sudah cukup melimpah di daerah-daerah tertentu khususnya di desa kelampangan palangka raya dimana sampel diambil dimana alangkah baiknya arang batok kelapa dapat digunakan oleh masyarakat sebagai materal pembuatan beton. Dalam penelitian ini rancangan campuran beton yang dipakai adalah rancangan campuran acak lengkap, dimana dilakukan 4 (empat) perlakuan persentase penambahan arang batok kelapa terhadap pengurangan persentase agregat halus (pasir) $0 \%, 7,5 \%, 10 \%$ dan $12,5 \%$.

\section{Rumusan Masalah}

Adapun rumusan masalah dalam penelitian ini adalah untuk mengetahui berapakah kuat tekan beton K225 dengan pemakaian arang batok kelapa dengan prosentase $7,5 \%, 10 \%$, dan $12,5 \%$ terhadap agregat halus (pasir)?

\section{Tujuan Penelitian}

Tujuan dari dilakukan penelitian ini adalah untuk mendapatkan hasil kuat tekan beton K225 dengan pemakaian arang batok kelapa dengan prosentase $7,5 \%, 10 \%$, dan $12,5 \%$ terhadap agregat halus (pasir).

\section{KAJIAN PUSTAKA}

Beton adalah material komposit yang rumit, beton dapat dibuat oleh mereka yang tidak punya pengertian sama sekali tentang beton teknologi, tetapi pengertian yang salah dari kesederhanaan ini sering menjadi persoalan pada produk antara lain reputasi jelek dari beton sebagai materi bangunan.

Bahan utama beton adalah semen, agregat halus, agregat kasar, air serta bahan lain dengan perbandingan tertentu. Karena beton merupakan komposit, maka kualitas beton beton sangat tergantung dari kualitas masing-masing material pembentuk (Tjokrodimulyono,1992). Sifat dan karakteristik beton:

1. Karakteristik beton adalah mempunyai tegangan hancur tekan yang tinggi serta tegangan hancur tarik yang rendah.

2. Beton tidak dapat dipergunakan pada elemen konstruksi yang memikul momen lengkung atau tarikan.

3. Beton sangat lemah dalam menerima gaya tarik, sehingga akan terjadi retak yang makin lama makin besar.

4. Proses kimia pengikatan semen dengan air 
Pengaruh Pemakaian Arang Batok Kelapa ..., Dodi ${ }^{(1)}, \operatorname{Hendra}^{(2)}, \operatorname{Rida}^{(3)}$

menghasilkan panas dan dikenal dengan proses hidrasi.

5. Air berfungsi juga sebagai pelumas untuk mengurangi gesekan antar butiran sehingga beton dapat dipadatkan dengan mudah.

6. Kelebihan air dari jumlah yang dibutuhkan akan menyebabkan butiran semen berjarak semakin jauh sehingga kekuatan beton akan berkurang.

7. Dengan perkiraan komposisi (mix desain) dibuat rekayasa untuk memeriksa dan mengetahui perbandingan campuran agar dihasilkan kekuatan beton yang tinggi.

8. Selama proses pengerasan campuran beton, kelembaban beton harus dipertahankan untuk mendapatkan hasil yang direncanakan.

9. Setelah 28 hari, beton akan mencapai kekuatan penuh dan elemen konstruksi akan mampu memikul beban luar yang bekerja padanya.

10. Untuk menjaga keretakan yang lebih lanjut pada suatu penampang balok, maka dipasang tulangan baja pada daerah yang tertarik.

11. Pada beton bertulang memanfaatkan sifat beton yang kuat dalam menerima gaya tekan serta tulangan baja yang kuat menerima gaya tarik.

12. Dari segi biaya, beton menawarkan kemampuan tinggi dan harga yang relative rendah.

13. Beton hampir tidak memerlukan perawatan dan masa konstruksinya mencapai 50 tahun serta elemen konstruksinya yang mempunyai kekakuan tinggi serta aman terhadap bahaya kebakaran.

14. Salah satu kekurangan yang besar adalah berat sendiri konstruksi dan

15. Kelemahan lainnya adalah perubahan volume sebagai fungsi waktu berupa susut dan rangkak.

\section{Jenis-jenis beton}

1. Beton Ringan

2. Beton Hampa

3. Beton Bertulang

4. Beton Prategang
5. Beton Pracetak

METODE PENELITIAN

Bagan Alir Penelitian 
Pengaruh Pemakaian Arang Batok Kelapa ..., Dodi ${ }^{(1)}, \operatorname{Hendra}^{(2)}, \operatorname{Rida}^{(3)}$

\section{Bagan Alir Penelitian}

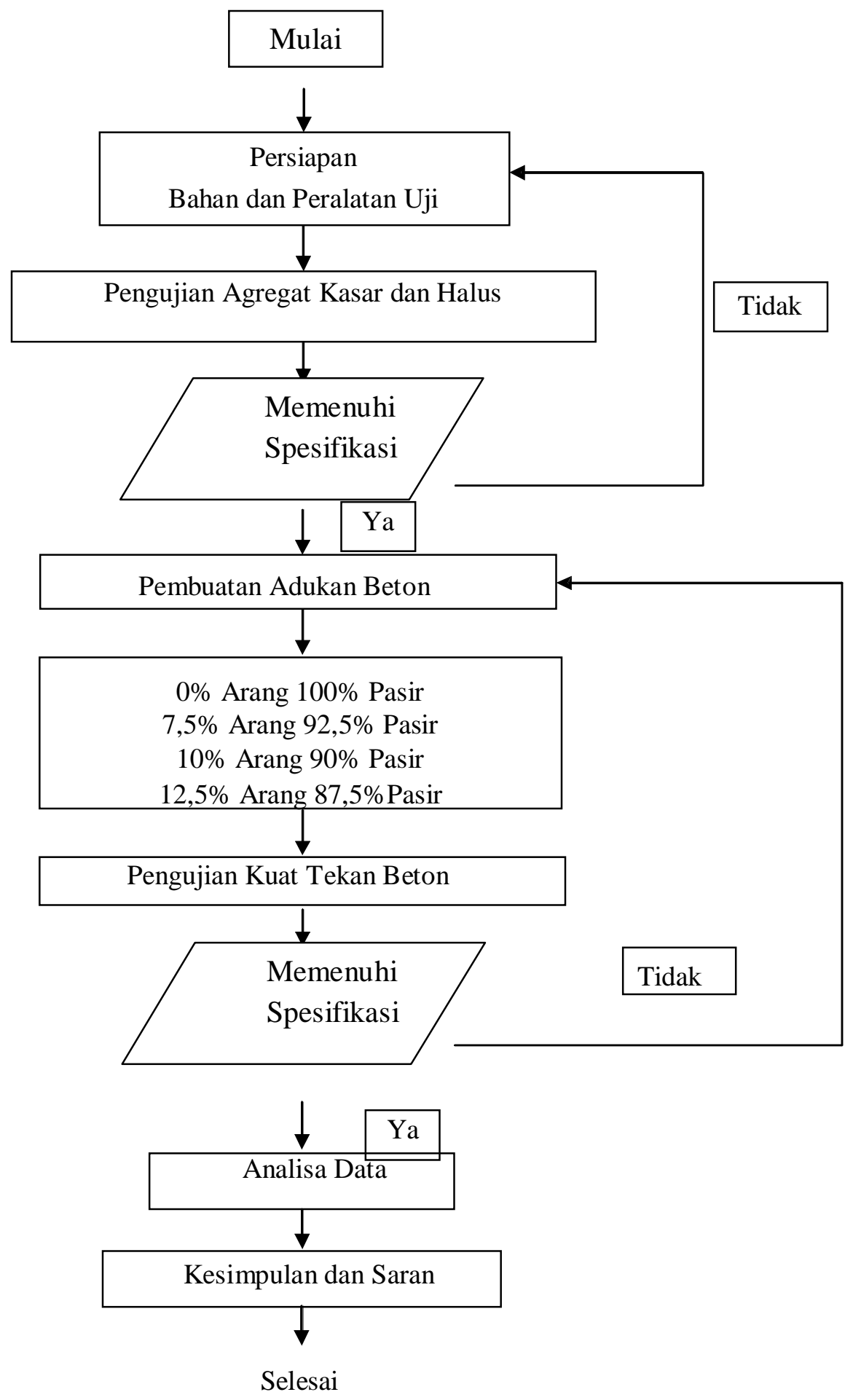

Gambar 1 Tahapan Penelitian 
Pengaruh Pemakaian Arang Batok Kelapa ..., Dodi ${ }^{(1)}, \operatorname{Hendra}^{(2)}$, Rida ${ }^{(3)}$

Diagram alir penelitian dapat dijelaskan sebagai berikut:

1. Kegiatan dimulai dengan tahap persiapan material (semen, pasir, air, batu pecah), dan arang batok kelapa sebagai bahan campuran.

2. Pengujian masing-masing agregat apakah memenusi spesifikasi yang disyaratkan, jika memenuhi maka dilanjutkan pembuatan desain campuran dan pembuatan beton kubus untuk sampel benda uji.

3. Sampel benda uji yang berjumlah 36 kubus beton dilakukan pengujian kuat tekan sesuai umur yang telah ditentukan.
4. Jika uji kuat tekan memenuhi syarat maka dilakukan analisis perhitungan hasil kuat tekan beton, jika tidak memenuhi syarat maka kembali ke pembuatan campuran beton.

5. Setelah dilakukan analisis data maka ditarik kesimpulan dan selesai.

\section{HASIL DAN PEMBAHASAN}

\section{Hasil Perencanaan Campuran Beton K225}

Dari perhitungan sesuai acuan standart SK SNI T-15-1990-03 di peroleh komposisi rancangan campuran seperti terlihat pada Tabel 1 berikut:

Tabel 1 Komposisi Campuran Beton K225

\begin{tabular}{|c|c|c|c|c|c|}
\hline $\begin{array}{l}\text { Kelas } \\
\text { Beton }\end{array}$ & \multicolumn{2}{|c|}{ Umur Beton (Hari) } & $\begin{array}{c}\text { Kuat Tekan } \\
\left(\mathrm{Kg} / \mathrm{Cm}^{2}\right)\end{array}$ & $\begin{array}{c}\text { Kuat Tekan } \\
\text { Konversi } \\
28 \text { Hari } \\
\left(\mathrm{Kg} / \mathrm{Cm}^{2}\right) \\
\end{array}$ & $\begin{array}{c}\text { Kuat Tekan } \\
\text { Rata-Rata } \\
\left(\mathrm{Kg} / \mathrm{Cm}^{2}\right)\end{array}$ \\
\hline \multirow{9}{*}{$\mathrm{K}-225$} & \multirow{3}{*}{3} & Sampel I & 168.89 & 383.84 & \multirow{3}{*}{390.57} \\
\hline & & Sampel II & 173.33 & 393.94 & \\
\hline & & Sampel III & 173.33 & 393.94 & \\
\hline & \multirow{3}{*}{7} & Sampel I & 195.56 & 300.85 & \multirow{3}{*}{298.58} \\
\hline & & Sampel II & 195.56 & 300.85 & \\
\hline & & Sampel III & 191.11 & 294.02 & \\
\hline & \multirow{3}{*}{14} & Sampel I & 208.89 & 237.37 & \multirow{3}{*}{254.21} \\
\hline & & Sampel II & 222.22 & 252.53 & \\
\hline & & Sampel III & 240.00 & 272.73 & \\
\hline
\end{tabular}

Grafik Kuat Tekan Rata-Rata

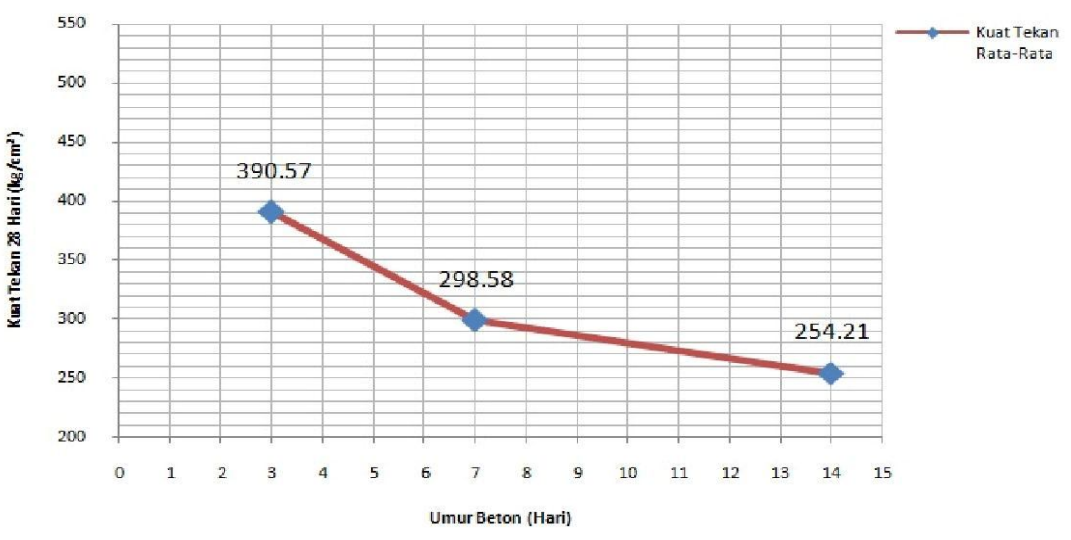

Gambar 2 Grafik Kuat Tekan Rata-Rata Beton Normal 
Pengaruh Pemakaian Arang Batok Kelapa ..., Dodi ${ }^{(1)}, \operatorname{Hendra}^{(2)}$, Rida ${ }^{(3)}$

Dari Tabel 2 dan Gambar 2 terdapat 9 (Sembilan) sampel beton kubus yang dipakai untuk pengujian pada umur ke 3, 7 dan 14 hari. Dilihat bahwa pada umur 3 hari kuat tekan ratarata $390.57 \mathrm{~kg} / \mathrm{cm}^{2}$, umur 7 hari kuat tekan 298.58 $\mathrm{kg} / \mathrm{cm}^{2}$, dan umur 14 hari kuat tekan 254.21 $\mathrm{kg} / \mathrm{cm}^{2}$.

\section{Beton Dengan Campurn A rang Batok Kelapa 7,5\%}

Adapun karakteristik beton K-225 setelah dicampur dengan arang batok kelapa, dapat dilihat pada Tabel 3 dan Gambar 3 berikut:

Tabel 3 Karakteristik Beton K-225dengan Campuran Arang Batok Kelapa 7,5\%

\begin{tabular}{|c|c|c|c|c|c|}
\hline $\begin{array}{l}\text { Kelas } \\
\text { Beton }\end{array}$ & \multicolumn{2}{|c|}{$\begin{array}{l}\text { Umur Beton } \\
\text { (Hari) }\end{array}$} & \multirow{2}{*}{$\begin{array}{c}\begin{array}{c}\text { Kuat } \\
\text { Tekan } \\
\left(\mathrm{Kg} / \mathrm{Cm}^{2}\right)\end{array} \\
186.67\end{array}$} & \multirow{2}{*}{$\begin{array}{c}\begin{array}{c}\text { Kuat Tekan } \\
\text { Konversi } 28 \\
\text { Hari } \\
\left(\mathrm{Kg} / \mathrm{Cm}^{2}\right)\end{array} \\
424.24\end{array}$} & \multirow[t]{2}{*}{$\begin{array}{c}\text { Kuat } \\
\text { Tekan } \\
\text { Rata- } \\
\text { Rata } \\
\left(\mathrm{Kg} / \mathrm{Cm}^{2}\right)\end{array}$} \\
\hline \multirow{9}{*}{$\begin{array}{c}\mathrm{K}- \\
225\end{array}$} & \multirow{3}{*}{3} & $\begin{array}{l}\text { Sampel } \\
\text { I }\end{array}$ & & & \\
\hline & & $\begin{array}{l}\text { Sampel } \\
\text { II }\end{array}$ & 173.33 & 393.94 & \multirow[t]{2}{*}{410.77} \\
\hline & & $\begin{array}{l}\text { Sampel } \\
\text { III }\end{array}$ & 182.22 & 414.14 & \\
\hline & \multirow{3}{*}{7} & $\begin{array}{l}\text { Sampel } \\
\text { I }\end{array}$ & 213.33 & 328.21 & \multirow{3}{*}{335,04} \\
\hline & & $\begin{array}{l}\text { Sampel } \\
\text { II }\end{array}$ & 226.67 & 348.72 & \\
\hline & & $\begin{array}{l}\text { Sampel } \\
\text { III }\end{array}$ & 213.33 & 328.21 & \\
\hline & \multirow{3}{*}{14} & $\begin{array}{l}\text { Sampel } \\
\text { I }\end{array}$ & 231.11 & 262.63 & \multirow{3}{*}{274.11} \\
\hline & & $\begin{array}{l}\text { Sampel } \\
\text { II }\end{array}$ & 240.00 & 272.73 & \\
\hline & & $\begin{array}{l}\text { Sampel } \\
\text { III }\end{array}$ & 253.33 & 287.88 & \\
\hline
\end{tabular}

Grafik Kuat Tekan

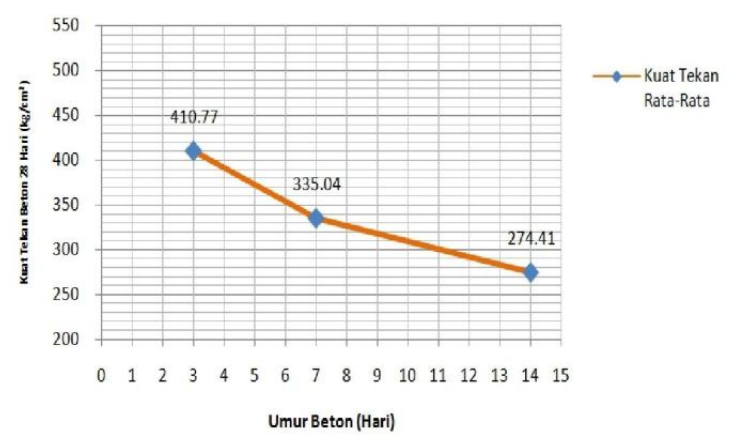

Gambar 3 Grafik Kuat Tekan Rata-Rata Beton Dengan Campuran Arang 7,5\%
Dari Tabel 3 Gambar 3 terdapat 9 (Sembilan) sampel beton kubus yang dipakai untuk pengujian pada umur ke 3, 7 dan 14 hari. Dilihat bahwa pada umur 3 hari kuat tekan ratarata $410,77 \mathrm{~kg} / \mathrm{cm}^{2}$, umur 7 hari kuat tekan 335,04 $\mathrm{kg} / \mathrm{cm}^{2}$, dan umur 14 hari kuat tekan 274,11 $\mathrm{kg} / \mathrm{cm}^{2}$.

\section{Beton Dengan Campuran Arang Batok Kelapa $10 \%$}

Adapun karakteristik beton K-225 setelah dicampur dengan arang batok kelapa $10 \%$, dapat dilihat pada Tabel 4 dan Gambar 4 berikut:

Tabel 4 Karakteristik Beton K-225Dengan Campuran Arang Batok Kelapa 10\%

\begin{tabular}{|c|c|c|c|c|c|}
\hline $\begin{array}{l}\text { Kelas } \\
\text { Beton }\end{array}$ & \multicolumn{2}{|c|}{$\begin{array}{l}\text { Umur Beton } \\
\text { (Hari) }\end{array}$} & $\begin{array}{c}\text { Kuat } \\
\text { Tekan } \\
\left(\mathrm{Kg} / \mathrm{Cm}^{2}\right)\end{array}$ & $\begin{array}{c}\text { Kuat Tekan } \\
\text { Konversi } 28 \\
\text { Hari } \\
\left(\mathrm{Kg} / \mathrm{Cm}^{2}\right)\end{array}$ & $\begin{array}{c}\text { Kuat } \\
\text { Tekan } \\
\text { Rata- } \\
\text { Rata } \\
\left(\mathrm{Kg} / \mathrm{Cm}^{2}\right)\end{array}$ \\
\hline \multirow{9}{*}{ K-225 } & \multirow{3}{*}{3} & Sampel I & 173.33 & 393.94 & \multirow{3}{*}{393.94} \\
\hline & & $\begin{array}{l}\text { Sampel } \\
\text { II }\end{array}$ & 177.78 & 404.04 & \\
\hline & & $\begin{array}{l}\text { Sampel } \\
\text { III }\end{array}$ & 168.89 & 383,84 & \\
\hline & \multirow{3}{*}{7} & Sampel I & 213.33 & 328.33 & \multirow{3}{*}{335.04} \\
\hline & & $\begin{array}{l}\text { Sampel } \\
\text { II }\end{array}$ & 217.78 & 217.78 & \\
\hline & & $\begin{array}{l}\text { Sampel } \\
\text { III }\end{array}$ & 222.22 & 341.88 & \\
\hline & \multirow{3}{*}{$\begin{array}{l}1 \\
4\end{array}$} & Sampel I & 235.56 & 267.68 & \multirow{3}{*}{269.36} \\
\hline & & $\begin{array}{l}\text { Sampel } \\
\text { II }\end{array}$ & 244.44 & 277.78 & \\
\hline & & $\begin{array}{l}\text { Sampel } \\
\text { III }\end{array}$ & 231.11 & 262.63 & \\
\hline
\end{tabular}

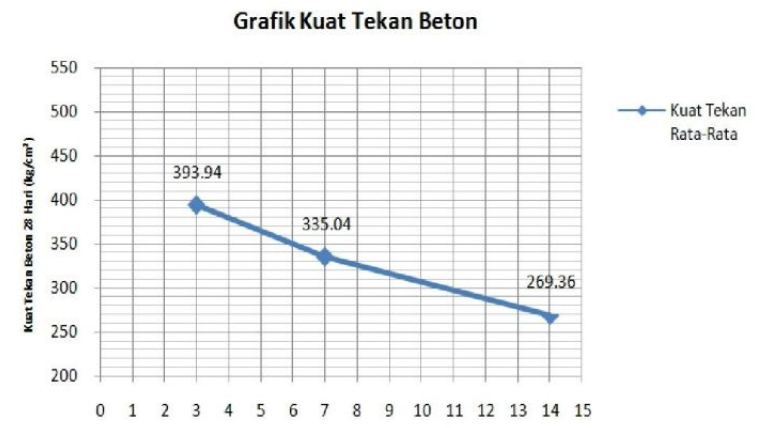

Umur Beton (Hari)

Gambar 4 Grafik Kuat Tekan Rata-Rata Beton Dengan Campuran Arang 10\%

Dari Tabel 4 dan Gambar 4 terdapat 9 (Sembilan) sampel beton kubus yang dipakai untuk pengujian pada umur ke 3, 7 dan 14 hari. Dilihat bahwa pada umur 3 hari kuat tekan rata- 
Pengaruh Pemakaian Arang Batok Kelapa ..., Dodi ${ }^{(1)}, \operatorname{Hendra}^{(2)}$, Rida ${ }^{(3)}$

rata $393,94 \mathrm{~kg} / \mathrm{cm}^{2}$, umur 7 hari kuat tekan 335,04 $\mathrm{kg} / \mathrm{cm}^{2}$, dan umur 14 hari kuat tekan 269,36 $\mathrm{kg} / \mathrm{cm}^{2}$. Dapat dikatakan bahwa kuat tekan mengalami penurunan seiring bertambahnya umur beton. Namun, masih memenuhi syarat kuat tekan rencana beton K-225.

\section{Beton Dengan Campuran Arang Batok Kelapa 12,5\%}

Adapun karakteristik beton K-225 setelah dicampur dengan arang batok kelapa 12,5\%, dapat dilihat pada Tabel 5 dan Gambar 5 berikut: Tabel 5 Karakteristik Beton K-225dengan campuran Arang Batok Kelapa 12,5\%

\begin{tabular}{|c|c|c|c|c|c|}
\hline $\begin{array}{l}\text { Kelas } \\
\text { Beton }\end{array}$ & \multicolumn{2}{|c|}{$\begin{array}{l}\text { Umur Beton } \\
\text { (Hari) }\end{array}$} & \multirow{2}{*}{$\begin{array}{c}\begin{array}{c}\text { Kuat } \\
\text { Tekan } \\
\left(\mathrm{Kg} / \mathrm{Cm}^{2}\right)\end{array} \\
164.44\end{array}$} & \multirow{2}{*}{$\begin{array}{l}\begin{array}{c}\text { Kuat Tekan } \\
\text { Konversi } 28 \\
\begin{array}{c}\text { Hari } \\
\left(\mathrm{Kg} / \mathrm{Cm}^{2}\right)\end{array} \\
373.74\end{array}\end{array}$} & \multirow{2}{*}{$\begin{array}{c}\text { Kuat } \\
\text { Tekan } \\
\text { Rata- } \\
\text { Rata } \\
\left(\mathrm{Kg} / \mathrm{Cm}^{2}\right)\end{array}$} \\
\hline \multirow{9}{*}{ K-225 } & \multirow{3}{*}{3} & $\begin{array}{l}\text { Sampel } \\
\text { I }\end{array}$ & & & \\
\hline & & $\begin{array}{l}\text { Sampel } \\
\text { II }\end{array}$ & 168.89 & 383.84 & \multirow[t]{2}{*}{367.00} \\
\hline & & $\begin{array}{l}\text { Sampel } \\
\text { III }\end{array}$ & 151.11 & 343.43 & \\
\hline & \multirow{3}{*}{7} & $\begin{array}{l}\text { Sampel } \\
\text { I }\end{array}$ & 182.22 & 280.34 & \multirow{3}{*}{294.02} \\
\hline & & $\begin{array}{l}\text { Sampel } \\
\text { II }\end{array}$ & 200.00 & 307.69 & \\
\hline & & $\begin{array}{l}\text { Sampel } \\
\text { III }\end{array}$ & 191.11 & 294.02 & \\
\hline & \multirow{3}{*}{14} & $\begin{array}{l}\text { Sampel } \\
\text { I }\end{array}$ & 213.33 & 242.42 & \multirow{3}{*}{254.21} \\
\hline & & $\begin{array}{l}\text { Sampel } \\
\text { II }\end{array}$ & 231.11 & 262.63 & \\
\hline & & $\begin{array}{l}\text { Sampel } \\
\text { III }\end{array}$ & 226.67 & 257.58 & \\
\hline
\end{tabular}

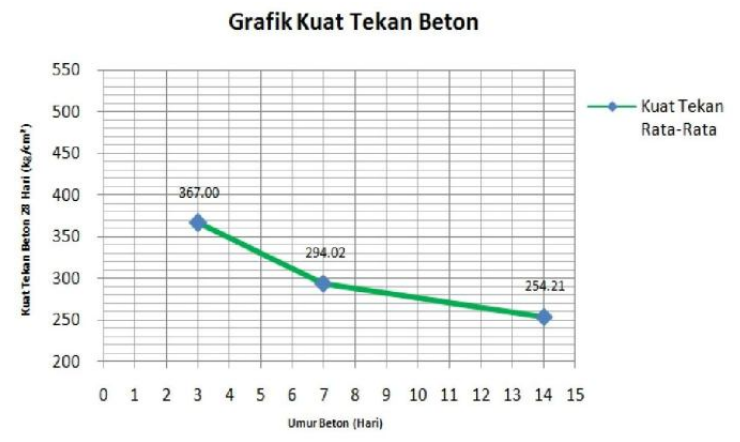

Gambar 5 Grafik Kuat Tekan Rata-Rata Beton Dengan Campuran Arang 12,5\%

Dari Tabel 5 dan Gambar 5 terdapat 9 (Sembilan) sampel beton kubus yang dipakai untuk pengujian pada umur ke 3, 7 dan 14 hari. Dilihat bahwa pada umur 3 hari kuat tekan rata- rata $367,00 \mathrm{~kg} / \mathrm{cm}^{2}$, umur 7 hari kuat tekan 294,02 $\mathrm{kg} / \mathrm{cm}^{2}$, dan umur 14 hari kuat tekan 254,21 $\mathrm{kg} / \mathrm{cm}^{2}$.

\section{Rekapitulasi Hasil Uji Kuat Tekan Beton}

Rekapitulasi hasil penelitian dapat dilihat pada Tabel 6 dan Gambar 6 berikut Tabel 6 Perbandingan Kuat Tekan Beton Normal dan Campuran Arang Batok Kelapa.

\begin{tabular}{|l|l|l|}
\hline Variasi Campuran & Umur & $\begin{array}{c}\text { Kuat Tekan Rata- } \\
\text { Rata }\left(\mathrm{Kg} / \mathrm{Cm}^{2}\right)\end{array}$ \\
\hline \multirow{4}{*}{ Beton Normal } & 3 & 390.57 \\
\cline { 2 - 3 } & 7 & 298.58 \\
\cline { 2 - 3 } & 14 & 254.21 \\
\hline \multirow{2}{*}{$\begin{array}{l}\text { Arang Batok Kelapa } \\
\text { 7,5 }\end{array}$} & 3 & 410.77 \\
\cline { 2 - 3 } & 7 & 335,04 \\
\cline { 2 - 3 } $\begin{array}{l}\text { Arang Batok Kelapa } \\
\text { 10\% }\end{array}$ & 3 & 274.11 \\
\cline { 2 - 3 } & 7 & 393.94 \\
\cline { 2 - 3 } & 14 & 269.36 \\
\hline \multirow{2}{*}{$\begin{array}{l}\text { Arang Batok } \\
\text { Kelapa 12,5 }\end{array}$} & 3 & 367.00 \\
\cline { 2 - 3 } & 7 & 294.02 \\
\cline { 2 - 3 } & 14 & 254.21 \\
\hline
\end{tabular}

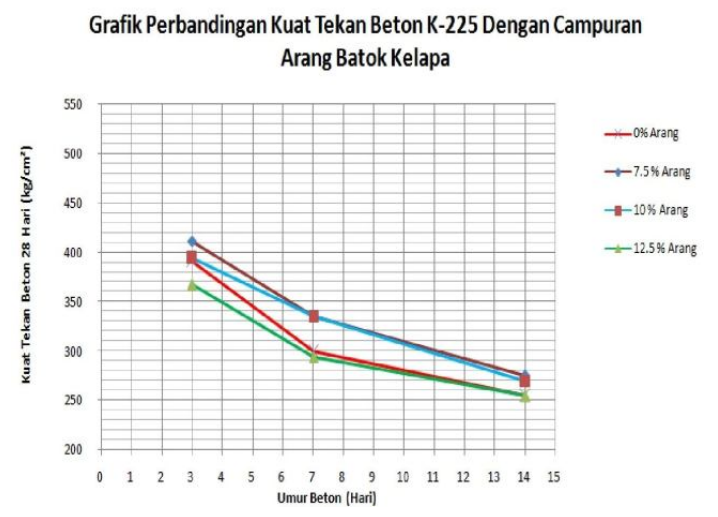

Gambar 6 Grafik Perbandingan Kuat Tekan Beton Normal dan Campuran Arang Batok Kelapa

Dari Tabel 6 dan Gambar 6 dapat dilihat perbandingan empat pengujian yang berbeda dengan proporsi campuran yang berbeda. Kekuatan tekan tertinggi dicapai oleh beton 
dengan campuran arang batok kelapa 7,5\% kemudian terlihat menurun pada campuran $10 \%$ arang batok kelapa namun masih diatas beton normal, baru terjadi penurunan kuat tekan pada campuran $12,5 \%$ arang batok kelapa dari beton.

\section{KESIMPULAN}

Berdasarkan hasil penelitian, maka didapat kesimpulan sebagai berikut:

1. Kuat tekan beton normal adalah 314,45 $\mathrm{kg} / \mathrm{cm}^{2}$

2. Percobaan pertama dengan mengganti $7,5 \%$ arang batok kelapa terhadap agregat halus (pasir) diperoleh hasil sebesar $340,08 \mathrm{~kg} / \mathrm{cm}^{2}$

3. Percobaan kedua dengan mengganti $10 \%$ arang batok kelapa terhadap agregat halus (pasir) diperoleh hasil sebesar $332,78 \mathrm{~kg} / \mathrm{cm}^{2}$

4. Percobaan ketiga dengan mengganti $12,5 \%$ arang batok kelapa terhadap agregat halus (pasir) diperoleh hasil sebesar $305,08 \mathrm{~kg} / \mathrm{cm}^{2}$

5. Kuat tekan maksimal di dapat pada percobaan pertama dengan mengganti $7,5 \%$ arang batok kelapa terhadap agregat halus (pasir) dengan kenaikan kuat tekan sebesar $25,63 \mathrm{Kg} / \mathrm{cm}$ dari kuat tekan beton normal.

6. Kuat tekan minimal pada percobaan terakhir dengan mengganti $12,5 \%$ arang batok kelapa terhadap agregat halus (pasir) kekuatan tekan mengalami penurunan $27,70 \mathrm{Kg} / \mathrm{cm}^{2}$ dari kuat tekan beton normal.

\section{SARAN} ini adalah:

Saran yang bisa diberikan setelah penelitian

1. Karena bersifat campuran pengganti, pemakaian arang batok kelapa perlu ketelitian pengawasan dan pengujian untuk penggunaanya dalam skala besar.

2. Disarankan digunakan hanya untuk wilayah-wilayah yang memang sudah banyak terdapat arang batok kelapa.

3. Pemakaian arang batok kelapa dapat menaikan kuat tekan beton, namun perlu disarankan penelitian selanjutnya apakah dapat digunakan pada beton di atas K225.

\section{DAFTAR PUSTAKA}

ACI Internasional Confrence, 1997, High Performance Concrete and Design Materials and Recend Advance is Concretet.

Balaguru, P. and Shah, S.P., Fibre einforced Cement Composites, McGraw-Hill, Singapore,1992. Callister,W.,D., 1997. "Materials Scienc\& Engineering" John Wiley \& Sons, Inc

Fakultas Teknik Sipil, Pedoman Praktikum Beton, Laboratorium Struktur Universitas Muhammadyah Palangkaraya.

Gustaferro, A. H. 1987. "Fire Resistance", Handbook of Concrete Engineering (Ed. Mark Fintel), Van Nostrand Reinhold Company, New York, 1 - 40.

Mediyanto A., dkk, 2004. "Kajian Sifat Mekanik Dan Kapasitas Elemen Struktural Beton Ringan Berserat".Penelitian Hibah Pekerti, UNS.

Partowiyatmo, A. and Sudarmadi, 2004. "Strength Recovery of Fire Concrete", Proceedings of the $7^{\text {th }}$ International Conference on Quality in Research (QIR), University of Indonesia, Jakarta.6 pp.

Sudarmoko, 1993, Pengaruh Panjang Serat Pada Sifat Struktural Beton Serat,Media Teknik No. 1 Tahun XV, Yogyakarta

Suhendro, B., 1991, Pengaruh Fiber Kawat Pada Sifat-Sifat Beton, Seminar Mekanika Bahan Dalam Berbagai Aspek, Yogyakarta

Suhendro, B. 1991. "Pengaruh Pemakaian Fiber Secara Parsial pada Perilaku dan Kapasitas Balok Beton Bertulang”, Prosiding Seminar Mekanika Bahan Untuk Meningkatkan Potensi Bahan Lokal, PAU UGM.

Standart Nasional Indonesia, SNI 03-2834-1993. "Tata Cara Campuran Beton Normal", Pustajatan-Balitbang Pekerjaan Umum, Bandung. 